\title{
An empirically grounded framework to guide blogging for digital scholarship
}

\author{
Tania Heap ${ }^{\mathrm{a} *}$ and Shailey Minocha ${ }^{\mathrm{b}}$ \\ ${ }^{a}$ Centre for Research in Education and Educational Technology, The Open University, Walton \\ Hall, Milton Keynes, UK, ${ }^{b}$ Computing Department, The Open University, Walton Hall, Milton \\ Keynes, $U K$
}

(Received 12 March 2012; final version received 30 May 2012)

This research project investigated how openness and sharing of knowledge are manifested through scholarly blogging. We aimed to identify the academics' and researchers' motivations for starting a blog; the contribution of blogging to their personal and professional development; and any challenges. Twenty-six participants were recruited. A pre-interview questionnaire was first emailed to the participants to collect background information. An initial unstructured interview was conducted by email, followed by a synchronous semi-structured interview. Textual and visual extracts of blog content were also collected. The datasets were analysed using different techniques. The findings revealed varied reasons for blogging. Some academics/researchers began a blog for its accessibility to self and others. Blogging aided the academics' and researchers' personal and professional development in several ways. Bloggers can quickly reach a wider audience compared to other forms of academic publishing. Among the challenges, there were concerns over validity of online content. Based on previous scholarship models and on our findings, we have derived an empirically grounded framework of blog use in academia and research. The framework describes how characteristics of digital scholarship such as openness and sharing are manifested through blogging. The framework can be used to guide academics and researchers who are interested in taking up blogging as a scholarly practice.

Keywords: academic blogging; research blogging; openness; digital scholarship; open scholarship

\section{Introduction}

We investigated the blogging practices of individual academics and researchers. We looked at the motivations for their starting and maintaining a blog as part of their scholarly practice. We also examined the benefits and challenges of blogging in academia and research.

The empirical investigations involved collating experiences of participants in different higher education institutions (HEIs) and countries, and from varied subjectdisciplines. Our research builds on previous studies on the use of social software in education, and on blogging in particular, which have generally been small-scale.

The concept of "digital scholarship" is increasingly being used to refer to the use of social software in academia and research. Examples of social software tools are blogs, wikis, micro-blogging (e.g. Twitter), social-networking platforms

*Corresponding author. Email: t.p.heap@open.ac.uk 
(e.g. Facebook, Linkedin, Academia.edu). Digital scholarship is acknowledged as happening, but there are still reservations about recognising it for promotion, tenure and funding (e.g. Cheverie, Boettcher, and Buschman 2009; Weller 2011).

In this paper, we present an empirically grounded framework of blog use in academia and research. The framework describes how characteristics of digital scholarship such as openness and sharing of knowledge are manifested through blogging. The framework can guide and inform academics and researchers who are interested in taking up blogging as a scholarly practice.

\section{Blogging in educational contexts}

Blogs, that is, web pages used as online journals or diaries, have been around since the mid-1990s, but were initially more popular in journalism and business contexts (Bruns 2007). Since the early 2000s blogs have been embraced in education, and several studies have been carried out since then to investigate the effectiveness of blogs in teaching and learning.

Previous research on blogging has included studies on several categories of students: secondary, undergraduate, postgraduate, distance-learners, professional trainees. The effectiveness of blogging in facilitating several skills and activities has been well demonstrated: for personal reflection (e.g. Xie, Fengfeng, and Sharma 2008), collaborative working (e.g. McLoughlin and Lee 2008), developing writing skills (e.g. Warschauer 2010) and flexible usage of blogs to suit the individual blogger's needs, such as a space for reflection, to seek peer support, or both (e.g. Kerawalla et al. 2008).

Challenges in blogging relate to concerns over privacy and ownership of ideas (Armstrong and Franklin 2008). There are privacy issues if bloggers write under their true identity and are not careful about disclosing personal information, such as where they live. Blogging under a pseudonym or being cautious about revealing personal information can help minimise these challenges. Also, if a blog is in the public domain, it is possible for readers to access ideas and pass them as their own, particularly if some of the readers are blogging anonymously (Ellison and Wu 2008).

There are some limitations in the existing research on blogging in educational contexts.

Most social software initiatives in education are generally small-scale, led by an individual educator and situated within a single course or a module (Minocha 2009a). A number of case studies of social software use have been reported in the literature, but these have involved small samples, often conducted by the researcher within their institution (e.g. Kirkup 2010; Mortensen and Walker 2002; Ward and West 2008). Most of these studies have been conducted in English-speaking countries, with few exceptions (see reports by Armstrong and Franklin 2008; Sim and Hew 2010).

Studies that have investigated the role of blogging in research have focussed on early-career researchers, that is, doctoral and post-doctoral researchers (e.g. Ferguson, Clough, and Hosein 2010; Minocha and Kerawalla 2010; Ward and West 2008). There is still some conservatism in recognising the phenomenon of "digital scholarship", of which blogging is a part, towards tenure, promotion and funding (e.g. Cheverie, Boettcher, and Buschman 2009; Kirkup 2010; Weller 2011). There is also no agreement as yet on the effective ways of measuring the impact of digital 


\section{T. Heap and S. Minocha}

scholarship on the user's own practice and the wider community (Priem and Hemminger 2010).

In the next section, we discuss the concept of scholarship and its characteristics in the digital or social software age.

\section{Defining scholarship in the digital age}

Boyer (1990) developed a conceptual framework which defines "scholarship" as a combination of teaching and research activities. In particular, he suggests four dimensions to define scholarship: discovery, integration, application and teaching.

The first two dimensions indicate the development of new knowledge from one discipline (discovery) and from an interdisciplinary area (integration). Application refers to engagement within and outside academia in relation to the scholar's works. Teaching refers to all activities associated with preparing, assessing and supporting students' learning.

However, Boyer's (1990) framework focuses on the practice of individual scholars. It can explain the practice of a scholar working in the humanities. It is less useful to understand the practice of scholars working in teams, such as natural scientists, and those engaging with social media (Pearce et al. 2010; Weller 2011). Also, Boyer considers research and teaching as two separate entities, suggesting that the creation of new knowledge (discovery) becomes a part of teaching. This implies that the teacher has a more directional role (Garnett and Ecclesfield 2011) rather than being seen as a facilitator which is how educators are engaging with social software (Minocha 2009b).

Boyer's dimensions constitute an appropriate starting point for researching digital scholarship (Weller 2011). However, his scholarship model had validity over a decade ago: it, on its own, cannot explain the ethos of this new form of scholarship, particularly the "open" approach of social software (Garnett and Ecclesfield 2011; Pearce et al. 2010). Pearce et al. (2010) elaborated on Boyer's (1990) model to theorise a form of digital/open scholarship, arguing that it is:

more than just using information and communication technologies to research, teach and collaborate, but it is embracing the open values, ideology and potential of technologies born of peer-to-peer networking and wiki ways of working in order to benefit both the academy and society.

In relation to the first two of Boyer's dimensions, "discovery" and "integration", Pearce et al. (2010) argue that social software renders research data available to a wider public. As regards "application", new knowledge and findings are increasingly disseminated in blogs, through wikis, and in online open access journals. Considering "teaching", social software tools allow for teaching materials to be easily shared within the online public domain.

However, there is a lack of empirical evidence on how the openness and sharing manifested in blogging can influence academia, research and scholarship. Our research aimed to investigate blogging as an academic practice and to understand how it can impact on the learning technology community. In this paper, we present an empirically grounded framework which is one of our research outcomes. The framework can be applied to inform academics and researchers about blogging as a scholarly activity within the realm of digital scholarship. 


\section{Research questions (RQs)}

We addressed the following RQs to investigate the effectiveness and challenges of blogging for academics and researchers:

\section{RQ1: Why do academics and researchers engage in blogging?}

RQ1: Focuses on what motivates academics and researchers to start and maintain a blog.

RQ2: How does blogging contribute to the academics' and researchers' personal and professional development?

RQ2: Looks at the possible benefits of blogging for an individual academic and/or researcher, e.g. developing research-related skills, promoting work, making an impact.

RQ3: What challenges do academics and researchers face with blogging?

RQ3: Investigates the concerns of academics and researchers, or any precautionary measures they consider.

\section{Research methodology}

Twenty-six academics/researcher bloggers were recruited between February 2010 and May 2011. The majority of participants were affiliated with UK institutions, but over a third came from other countries, mostly from outside Europe and from nonEnglish speaking (e.g. Ethiopia, Japan, Mexico) areas.

The RQs were investigated using a range of methods as explained below.

\section{Collecting data}

Five datasets were collected. A questionnaire was first administered to collect background information about the bloggers. Then, an initial unstructured interview involving one open-ended question was conducted by email. A follow-on semistructured interview was carried out on Skype (http://www.skype.com) or by telephone. Blog content was collected in parallel: written and visual extracts, such as pictures embedded on the blog.

\section{Analysing data}

The data from pre-interview questionnaires were analysed to draw a profile of the sample in diagrammatic form (i.e. pie charts of country of origin or affiliation, subject disciplines, uses of other social software). The unstructured interview was analysed using descriptive phenomenology. The follow-on semi-structured interview was analysed using inductive thematic analysis. Written extracts of blog entries were analysed using discourse analysis (ethnography of communication). Visual extracts were analysed using thematic/saliency analysis (see Table 1).

A multi-method approach for data analyses was employed to combine the strengths of each technique. Descriptive phenomenology helps uncover the psychological experience, through coherent narratives (Langdridge 2007). Thematic analysis identifies the recurrent patterns in the sample and which are most relevant to the RQs. Inductive or thematic analysis is not bound to one theoretical or methodological framework (Braun and Clarke 2006), and our research too draws from more than one analytical paradigm. Saliency analysis looks at the importance of the theme 


\section{T. Heap and S. Minocha}

Table 1. Artefacts collected and data analysis techniques.

\begin{tabular}{ll}
\hline Artefact & \multicolumn{1}{c}{ Analytical technique } \\
\hline Pre-interview questionnaire & Quantitative analysis \\
Unstructured interview & Descriptive phenomenological psychology \\
Semi-structured interview & Inductive thematic analysis \\
Blog content analysis: textual data & $\begin{array}{l}\text { Discourse analysis (ethnography of communication) } \\
\text { Blog content analysis: visual data }\end{array}$ \\
Thematic analysis (with saliency analysis) \\
\hline
\end{tabular}

for one participant, and for the RQs even if it may not be recurrent (Buetow 2010). Discourse analysis focuses on the meanings of language and linguistic styles. The approach of ethnography of communication, in particular, tries to identify socio-cultural patterns in the speech of a community (academic blogging and bloggers) and what forms of communication are important to the community, and this should emerge from their blogging style and content (Saville-Troike 2003).

\section{A conceptual model for the semi-structured interview}

The semi-structured interview was the most important artefact for collecting data in that it, through synchronous interactions with the participant, allowed us to expand on or clarify information collected from other artefacts. A conceptual model was applied to provide some structure to the interview geared towards answering the RQs and to maintain a direction in the conversation.

The conceptual model was derived by combining and adapting:

- Kerawalla et al.'s (2008) framework of blogging in HE learning and teaching;

- Boyer's (1990) dimensions for defining scholarship.

During the interviews conducted by Kerawalla et al. four factors were identified as being important by the students:

- Perceptions of and need for an audience

- Perceptions of and need for community

- Utility of and need for comments

- Presentational style of blog content

Our conceptual model has been adapted to include factors which are relevant to researchers, e.g. development of research-related skills. The four factors of Kerawalla et al. (2008) together with our three RQs were used to formulate the semi-structured interview questions related to: audience, impact, academic/public engagement, skills development.

Table 2 shows the conceptual model which guided the formulation of the interview questions.

The specific adaptations from the two existing frameworks (Figure 1) are now explained.

In our conceptual model, Kerawalla et al.'s "audience" and "comments" dimensions have been grouped together as one component, called Audience. We felt that the dimensions of "audience" and "comments" covered similar aspects, the 
Table 2. A conceptual model for the semi-structured interview.

\begin{tabular}{|c|c|c|}
\hline Research questions & $\begin{array}{l}\text { Components of blogging in } \\
\text { academic/research contexts }\end{array}$ & $\begin{array}{c}\text { Sample interview questions } \\
\text { derived }\end{array}$ \\
\hline $\begin{array}{l}\text { \#1: Why do academics and } \\
\text { researchers blog? }\end{array}$ & $\begin{array}{l}\text { This is the first broad research } \\
\text { question, which encompasses } \\
\text { the issues broken down below, } \\
\text { and is tailored according to } \\
\text { response from other data sets } \\
\text { (blog content, unstructured } \\
\text { interview) }\end{array}$ & $\begin{array}{l}\text { What made you start blogging } \\
\text { in you current role? } \\
\text { Was it your own initiative or } \\
\text { was it suggested by someone } \\
\text { else? }\end{array}$ \\
\hline \multirow{4}{*}{$\begin{array}{l}\text { \#2: How does blogging } \\
\text { contribute to the academics' } \\
\text { and researchers' personal and } \\
\text { professional development? }\end{array}$} & Audience & $\begin{array}{l}\text { Whom do you aim your blog } \\
\text { at? }\end{array}$ \\
\hline & Impact & $\begin{array}{l}\text { Do you use the blog to generate } \\
\text { data for your research? }\end{array}$ \\
\hline & $\begin{array}{l}\text { Academic and public } \\
\text { engagement }\end{array}$ & $\begin{array}{l}\text { Do you disseminate knowledge } \\
\text { and findings through your } \\
\text { blog? }\end{array}$ \\
\hline & Skills development & $\begin{array}{l}\text { What are the activities that } \\
\text { work successfully through } \\
\text { blogging? }\end{array}$ \\
\hline \multirow[t]{4}{*}{$\begin{array}{l}\text { \#3: What challenges do } \\
\text { academics and researchers } \\
\text { experience with blogging? }\end{array}$} & Audience & $\begin{array}{l}\text { Can you think of an example } \\
\text { when your relationship with } \\
\text { the audience was problematic? } \\
\text { Were any of the comments } \\
\text { unhelpful? }\end{array}$ \\
\hline & Impact & $\begin{array}{l}\text { Was it difficult to store data } \\
\text { sets on your blog? }\end{array}$ \\
\hline & $\begin{array}{l}\text { Academic and public } \\
\text { engagement }\end{array}$ & $\begin{array}{l}\text { Were there any circumstances } \\
\text { in which you found difficult to } \\
\text { communicate your work? }\end{array}$ \\
\hline & Skills development & $\begin{array}{l}\text { Do you find the blog } \\
\text { unsuitable to perform certain } \\
\text { tasks? }\end{array}$ \\
\hline
\end{tabular}

former of a broader scope than the latter, because using the comment facility is one example of interaction between blogger and audience. The Audience in our model, therefore, incorporates both the perception of readers of the blog (audience) and the communication between blogger and readers through using the comment facility (comments).

The second dimension, Impact, includes the first two dimensions of Boyer, i.e. "discovery" and "integration". It implies looking at blog usage in creating new knowledge, e.g. collection and analysis of data in one field of research (discovery), and interpreting the new knowledge across disciplines such as writing a book to illustrate the application of knowledge in different contexts (integration).

We substituted the "community" dimension of Kerawalla et al. with Academic and public engagement, also to encompass Boyer's "application" dimension. This includes looking at a wider relationship with a specialist and non-specialist community.

Skills development encompasses "presentation", the fourth dimension in Kerawalla et al.'s framework, and Boyer's "teaching". The dimension of skills development addresses blog usage in relation to the development of research-related and teaching skills, writing and presentation. 


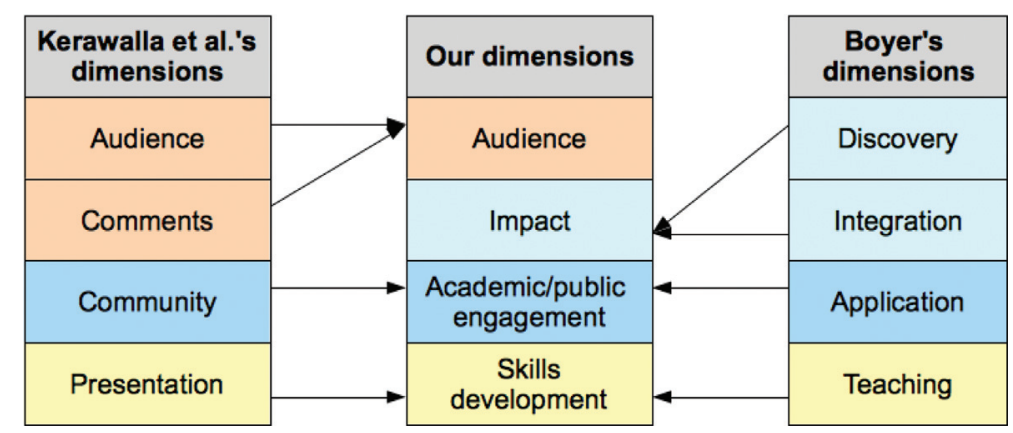

Figure 1. Combining Kerawalla et al.'s and Boyer's frameworks.

Table 2 shows a sample of the semi-structured interview questions derived from the conceptual model. The questions were, however, tailored to the individual participant's context and data from other artefacts, e.g. pre-interview questionnaire.

\section{Results}

A summary of the findings that emerged from analysing the data is presented in Table 3.

The themes that emerged in the data are discussed under three headings: motivation for blogging, benefits and associated challenges.

\section{Motivations for beginning a blog}

Academic and research bloggers began and maintained blogging for a variety of reasons. Some bloggers mentioned the need to have an archive where thoughts and experiences are recorded and to monitor their individual progress:

Participant 12 (P12): I've also found [blogging] a useful way to keep track of events I've attended and my reactions to them.

Many also mentioned the need to have a personal online space to reflect upon ideas and to experiment a different writing form:

P2: The blogging was an opportunity for me to experiment with some ideas, and explore and develop thoughts that I had.

Table 3. Summary of the findings.

\begin{tabular}{|c|c|c|}
\hline $\begin{array}{l}\text { Why do academics and } \\
\text { researchers blog (RQ1) }\end{array}$ & $\begin{array}{l}\text { Contribution to personal/ } \\
\text { professional development (RQ2) }\end{array}$ & Challenges (RQ3) \\
\hline $\begin{array}{l}\text { Repositories of } \\
\text { "half-baked" ideas }\end{array}$ & $\begin{array}{l}\text { Alternative/informal way of } \\
\text { dissemination }\end{array}$ & Validity of information \\
\hline To think and reflect & Make an impact & Preserving content \\
\hline Public experimentation & Networking/public engagement & Public vs private \\
\hline Accessibility & $\begin{array}{l}\text { Skills development (writing, self- } \\
\text { discipline, etc.) }\end{array}$ & Disappointing social interaction \\
\hline Construct online identity & & $\begin{array}{l}\text { Maintaining the } \\
\text { activity }\end{array}$ \\
\hline
\end{tabular}


Another reason that prompted some of them to start blogging was a need for an online presence as an academic or researcher, a space to construct and take control of their online public identity or persona. Some participants mentioned that the blog portrays a more informal identity, which can be customised by the user:

P13: I felt that my blog is a little bit attempting to take control of my web presence.

Therefore, portraying an online identity via blog could be more effective than using personal or institutional websites.

\section{The personal, social and professional benefits of blogging}

For some of the bloggers, the boundaries demarcating personal and professional development appeared blurred. The benefits that they perceived applied to both the spheres.

\section{Developing writing, self-discipline, interpersonal skills and networking}

Some participants commented on the usefulness of blogs to improve their skills of presentation and promoting writing and self-discipline, which are important on a personal and professional level. Blogs helped academics and researchers socially in a number of ways:

(1) in interacting with and presenting a piece of writing to an audience,

(2) in thinking about the audience and

(3) how they could write about issues that would be of value to their audience.

\section{Disseminating information}

The data revealed that blogs can be effective to disseminate knowledge and may make an impact on the bloggers' teaching and research. Blogs are perceived as a dissemination mode in a different way as compared to traditional forms of publishing. There was agreement on this aspect amongst bloggers who were at different stages of their careers: from the research student to the established researcher, from the digital scholarship advocate to somebody with not much enthusiasm about using blogs as a form of academic publishing.

\section{Complementarity with traditional publishing}

Blogs were perceived as complementing traditional forms of dissemination. Established forms of academic dissemination and publication are more rigorous, formal and ensure validity of information [although even this domain often presents challenges (e.g. Grant 2009), they do not appear to reach the wide audience the blogs can):

P7: blogging and other tools shouldn't replace traditional peer-reviewed journals but at the same time maybe the advantage of these new tools is that it disseminates information to beyond the specialist audience.

Several bloggers in the dataset argued in favour of using blogs to report research in progress whilst keeping traditional publications for the research outputs: 


\section{T. Heap and S. Minocha}

P15: I might put [half-baked ideas or initial thoughts] in my blog and then refine over time and then ultimately aspects of that might find their way into some more formal publication.

There are a few possible explanations for this preference. Traditional publications employ terminology, which may be difficult to understand for a non-specialist audience. Publications often require readers to be affiliated to an HE or research institution, or to purchase the articles to access them. Whilst rigour and validity may be ensured in traditional publications, the dissemination or possible impact outside academia, where findings may be relevant, might be minimal. Indeed, publications in open access journals receive more citations than those with restricted access (MacCallum and Parthasarathy 2006). The accessibility and informality of blogs may further help to fill the gap in public engagement and knowledge sharing.

\section{Complementarity with other social software}

What also emerged in our research is the complementarity of blogs with other social software tools such as micro-blogging (e.g. Twitter) and academic-oriented social networks which include an element of blogging, such as Cloudworks (http:// cloudworks.ac.uk). For some academics and researchers, the benefits of blogging are enhanced when complemented with other social software tools. For example, blogs can be used for longer and deeply thought reflections, and Twitter for disseminating brief salient pieces of information, such as URLs.

\section{The challenges of the new, the unfamiliar and the public}

Our findings confirmed that blogs, whilst effective for dissemination, present challenges regarding validity and ownership. The lack of recognition of the blog as a parallel form of dissemination by professional bodies poses a barrier to new forms of scholarship:

P24: I am afraid that [academic blogging] will remain something of an oddity (...) as long as there is little academic credit to be gained from it.

Another concern for many bloggers is the threat of revealing confidential information, blogs being in the public domain. There could be risks to the reputation of the individuals or to other people and institutions connected to the individual; hence, some bloggers kept a private or semi-private blog:

P4: ... I was involved in a project which was quite commercially sensitive (...) so I came up with a blog who was only accessed by me and another researcher.

Other challenges are associated with personal management such as time-management and self-discipline:

P3: sometimes I don't have the time to write on it and I would like to write on it more often but I can't.

Fear of an audience and instances when bloggers felt reluctant about going public was also noted among the challenges:

P9: you really have no idea [of who reads the blog] and I think at that point I started feeling a bit vulnerable. 
This was due to concerns over sharing sensitive information. Some beginner-bloggers also faced difficulties in finding their own style, and in being spontaneous when pressured by readers to write.

Finally, concerns over preserving digital content were noted. Some bloggers were worried about vulnerability of the data, others about its permanence on the Web and an inability to remove content at a later stage.

\section{Discussion}

We have found that blogs seem to occupy an intermediate space among established writing forms such as peer-reviewed academic papers, newspaper articles, diaries, blurring the private-public and formal-informal divide (Heap and Minocha 2011).

There is a growing awareness of blogging as a writing or communicative genre in academia and research and as a new form of scholarship (e.g. Halavais 2007). Whilst it is important to ensure validity of work through established forms of publishing, integrating blogs may help research findings to be known to more readers, specialist and non-specialist, for whom the findings may be relevant to their practice. Blogs also enable sharing information without time lags involved in formal publications.

The writing genre of academic blogging has these characteristics:

- Open: blogs enable a wider participation. However, openness has its challenges as blogs can be spaces for unsubstantiated opinions. This raises the challenge concerning validity of information, as noted in our findings.

- Collaborative: it enables collaboration and knowledge sharing, mediating relationships between bloggers and audience.

- User-generated: content is created and shared by blog users, which in turn makes them producers (Bruns 2007).

Boyer's framework of scholarship, therefore, needs to be reinterpreted in the current context. It does not consider the dynamic/cyclical knowledge collaboratively generated and shared using social software such as blogs. Garnett and Ecclesfield (2011) recognised that Boyer's model should be updated to define this form of open scholarship in the digital age. They theorised a co-creational model for scholarship, taking into account the emerging technology-driven practices. Pearce et al. (2010) proposed an updated framework to account for the trend towards openness in digital scholarship. However, they did not consider its collaborative, participative and dynamic nature (Veletsianos and Kimmons 2012).

With our empirical research, we have achieved what Garnett and Ecclesfield (2011) were recognising and we have overcome the shortcomings of Pearce et al. (2010).

\section{An empirically based framework for blogging in academia and research}

We have found that bloggers in our dataset cared about making an impact through blogging and by engaging with a wider community. Knowledge is disseminated more widely and quickly through blogging compared to traditional means of publishing. Blogs are often combined with other social software tools. Academics and researchers also note the possibilities offered by blogging in developing digital literacy skills such as writing online and in the public domain, and fostering 


\section{T. Heap and S. Minocha}

creativity. Challenges were also evident, in relation to producing knowledge in an open context (e.g. validity of unsubstantiated opinions), making an impact, in public engagement (e.g. managing reputation of self and institution) and developing skills (e.g. time-management).

The bloggers' experiences in our dataset, therefore, suggest that blogging as a scholarly practice is open, dynamic and social. By combining Boyer's scholarship model with Kerawalla et al.'s framework for blogging in education and our empirical findings, we have derived a framework for digital scholarship pursued through blogging (see Table 4).

We have extended the conceptual model employed in our empirical research (Table 2) to develop Heap's framework in Table 4. Audience has been incorporated into Academic and Public Engagement. This dimension focuses on the collaborative and social aspect of pursuing digital scholarship through blogging. Another dimension has been added to emphasise the openness of academic/research blogging. This new dimension incorporates our findings related to generating and disseminating knowledge not just collaboratively, but also openly: Open Knowledge Production. Each purpose of blogging is broken down into four dimensions. Each dimension is illustrated with an example of how this form of open and participative scholarship is manifested through blogging.

Academics and researchers wishing to take up blogging or other social software to support their practice can apply Heap's framework of scholarship. The framework guides how blogs can help in engaging with an audience and the associated

Table 4. Heap's framework of blog use in digital scholarship.

\begin{tabular}{|c|c|c|}
\hline Purpose & Type of scholarship & Description of scholarship through blogs \\
\hline \multirow[t]{4}{*}{$\begin{array}{l}\text { Motivation for beginning } \\
\text { and maintaining a blog }\end{array}$} & $\begin{array}{l}\text { Open knowledge } \\
\text { production }\end{array}$ & $\begin{array}{l}\text { Posting and archiving ideas in progress, } \\
\text { "half-baked" }\end{array}$ \\
\hline & Impact & $\begin{array}{l}\text { Need to construct and control an online } \\
\text { academic persona }\end{array}$ \\
\hline & $\begin{array}{l}\text { Audience and public } \\
\text { engagement }\end{array}$ & Being accessible to other people \\
\hline & Skills development & Experimenting writing online \\
\hline \multirow[t]{6}{*}{ Benefits of blogging } & $\begin{array}{l}\text { Open knowledge } \\
\text { production }\end{array}$ & $\begin{array}{l}\text { Informal and faster dissemination of } \\
\text { information }\end{array}$ \\
\hline & Impact & $\begin{array}{l}\text { Invitation by a blog reader to give keynote } \\
\text { presentation }\end{array}$ \\
\hline & & Promoting a book \\
\hline & $\begin{array}{l}\text { Audience and public } \\
\text { engagement }\end{array}$ & $\begin{array}{l}\text { Mediating relationships between } \\
\text { academics and non-academics }\end{array}$ \\
\hline & & $\begin{array}{l}\text { Complementing blogs with other social } \\
\text { software }\end{array}$ \\
\hline & Skills development & $\begin{array}{l}\text { Developing self-discipline; clarity in } \\
\text { writing }\end{array}$ \\
\hline \multirow[t]{4}{*}{ Challenges to address } & $\begin{array}{l}\text { Open knowledge } \\
\text { production }\end{array}$ & $\begin{array}{l}\text { Information and opinions presented in } \\
\text { blogs may be unsustained }\end{array}$ \\
\hline & Impact & $\begin{array}{l}\text { Content on blog is vulnerable, may } \\
\text { disappear for server problems }\end{array}$ \\
\hline & $\begin{array}{l}\text { Audience and public } \\
\text { engagement }\end{array}$ & $\begin{array}{l}\text { Care is needed when writing about third } \\
\text { parties (people, institutions) in public }\end{array}$ \\
\hline & Skills development & $\begin{array}{l}\text { Difficulties in maintaining the activity and } \\
\text { managing time }\end{array}$ \\
\hline
\end{tabular}


challenges. For example, academics/researchers may construct an online academic persona, combine blogging with other social software tools for networking, for promoting their book to an audience or for considering back-up measures for saving content. The framework can be used by educators and learning technologists to support students: to experiment writing in public and to develop presentation skills; to store notes, references and other resources relevant to the study materials or to encourage writing reflective responses to learning activities; and for conducting conversations outside a formal learning environment. Carrying out learning activities in an informal learning space may also make students less anxious about assessment.

The next steps in our research are to validate the effectiveness of the framework as a thinking tool about digital scholarship, and for guiding the practice of blogging in academia and research. This involves evaluating the framework with colleagues who already blog as a part of their practice, or who are considering adopting blogging for digital scholarship. The feedback will help us improve the framework. We have also developed empirically grounded guidelines on blogging, which we will share with colleagues in other publications in the near future.

\section{Acknowledgements}

The authors are grateful to Dr Rhona Sharpe (Oxford Brookes University), Dr Chris Jones and Dr Denise Whitelock (The Open University, UK) and the reviewers of this paper for their valuable insights and feedback.

\section{References}

Armstrong, J. \& Franklin, T. (2008) 'A review of current and developing international practice on the use of social networking (Web 2.0) in higher education', Report Commissioned by the Committee of Inquiry into the Changing Learner Experience, Franklin Consulting.

Boyer, E. L. (1990) Scholarship Reconsidered: Priorities of the Professoriate, Carnegie Foundation for the Advancement of Teaching, Princeton, NJ.

Braun, V. \& Clarke, V. (2006) 'Using thematic analysis in psychology', Qualitative Research in Psychology, vol. 3, no. 2, pp. 77-101.

Bruns, A. (2007) 'The practices of news blogging', in Uses of Blogs, eds A. Bruns \& J. Jacobs, 2nd edn, Peter Lang, New York.

Buetow, S. (2010) 'Thematic analysis and its reconceptualization as saliency analysis', Journal of Health Services Research and Policy, vol. 15, no. 2, pp. 123-125.

Cheverie, J. F., Boettcher, J. \& Buschman, J. (2009) 'Digital scholarship in the university tenure and promotion process: A report on the sixth scholarly communication symposium at Georgetown University Library', Journal of Scholarly Publishing, vol. 40, no. 3, pp. 219-230.

Ellison, N. B. \& Wu, Y. (2008) 'Blogging in the classroom: a preliminary exploration of student attitudes and impact on comprehension', Journal of Educational Multimedia and Hypermedia, vol. 17, no. 1, pp. 99-122.

Ferguson, R., Clough, G. \& Hosein, A. (2010) 'Shifting themes, shifting roles: the development of research blogs', in 'Into Something Rich and Strange' - Making Sense of the Sea-Change, The 17th Association for Learning Technology Conference (ALT-C 2010), 7-9 September, Nottingham, UK.

Garnett, F. \& Ecclesfield, N. (2011) 'Towards a framework for co-creating open scholarship', The 18th Association for Learning Technology Conference (ALT-C 2011), 6-8 September, Leeds University, Leeds, UK.

Grant, B. (2009) 'Elsevier published 6 fake journals', The Scientist, [online] Available at: http:// bit.ly/q7bXz3

Halavais, A. (2007) 'scholarly blogging: moving toward the visible college', in Uses of Blogs, eds A. Bruns \& J. Jacobs, Peter Lang, New York. 


\section{T. Heap and S. Minocha}

Heap, T. \& Minocha, S. (2011) 'The experiences of academic and research bloggers: a phenomenological enquiry', 30th International Human Science Research Conference: Intertwining body-self-world (IHSRC 2011), 27-30 July, St. Catherine's College, Oxford, UK.

Kerawalla, L. et al. (2008) 'Characterising the different blogging behaviours of students on an online distance learning course', Learning, Media and Technology, vol. 33, no. 1, pp. 21-33.

Kirkup, G. (2010) 'Academic blogging: academic practice and academic identity', London Review of Education, vol. 18, no. 1, pp. 75-84.

Langdridge, D. (2007) Phenomenological Psychology: Theory, Research and Method, Pearson/ Prentice Hall, Harlow.

MacCallum, C. J. \& Parthasarathy, H. (2006) 'Open access increases citation rate', PLoS Biology, vol. 4, no. 5, [online] Available at: http://bit.ly/qltKGc

McLoughlin, C. \& Lee, M. W. (2008) 'Future learning landscapes: transforming pedagogy through social software', Innovate: The Journal of Online Education, vol. 4, no. 5.

Minocha, S. (2009a) 'Effective use of social software in UK further and higher education: case studies', JISC Final Report (SOCIAL-SW), [online] Available at: http://tinyurl.com/ $5 \mathrm{a} 8 \mathrm{zu} 3$

Minocha, S. (2009b) 'A case study-based investigation of students' experiences with social software tools', New Review of Hypermedia and Multimedia, vol. 15, no. 3, pp. 245-265.

Minocha, S. \& Kerawalla, L. (2010) 'University Students' self-motivated blogging and development of study skills and research skills', in Web 2.0-Based E-Learning: Applying Social Informatics for Tertiary Teaching, eds M. J. W. Lee \& C. McLoughlin, IGI Global. pp. 149-179.

Mortensen, T. \& Walker, J. (2002) 'Blogging thoughts: Personal publication as an online research tool', in Researching ICTs in Context, ed. A. Morrison, InterMedia Report 3, University of Oslo, Norway.

Pearce, N., et al. (2010) 'Digital scholarship considered: how new technologies could transform academic work', In Education, vol. 16, no. 1, [online] Available at: http://bit.ly/wyDNky

Priem, J. \& Hemminger, B. M. (2010) 'Scientometrics 2.0: toward new metrics of scholarly impact in the social web', First Monday, vol. 15, no. 7, [online] Available at: http://bit.ly/ mC5AK 9

Saville-Troike, M. (2003) The Ethnography of Communication: An Introduction, Blackwell, Oxford.

Sim, J. W. S. \& Hew, K. F. (2010) 'The use of weblogs in higher education settings: a review of empirical research', Educational Research Review, vol. 5, no. 2, pp. 151-163.

Veletsianos, G. \& Kimmons, R. (2012) 'Networked participatory scholarship: emergent techno-cultural pressures toward open and digital scholarship in online networks', Computers \& Education, vol. 58, pp. 766-774.

Ward, M. H. \& West, S. (2008) 'Blogging PhD candidature: revealing the pedagogy', International Journal of Emerging Technologies and Society, vol. 6, no. 1, pp. 60-71.

Warschauer, M. (2010) 'Invited commentary: new tools for teaching writing', Language Learning and Technology, vol. 14, no. 1, pp. 3-8, [online] Available at: http://bit.ly/gfBjbU

Weller, M. (2011) The Digital Scholar: How Technology Is Transforming Scholarly Practice, Bloomsbury Academic, London.

Xie, Y., Fengfeng, K. \& Sharma, P. (2008) 'The effect of peer feedback for blogging on college students' reflective learning processes', The Internet and Higher Education, vol. 11, pp. 18-25. 